\title{
Rancang Bangun Sistem Informasi Resource Planning Desa (Studi Kasus: Desa Mojorejo)
}

\author{
Adi Bagus Setiawan ${ }^{* 1}$, Galih Wasis Wicaksono ${ }^{2}$, llyas Nuryasin ${ }^{3}$ \\ 1,2,3Teknik Informatika/Universitas Muhammadiyah Malang \\ adibagusgareng@gmail.com¹, galih.w.w@gmail.com²
}

\begin{abstract}
Abstrak
Sistem Informasi kini sudah tidak asing lagi dunia perusahaan dimana sistem informasi sangat dibutuhkan untuk sebuah perusahaan supaya dapat membantu suatu proses pekerjaan menjadi semakin mudah dan cepat. Sistem informasi merupakan suatu perangkat yang dapat mengolah data, menyimpan data, dan juga memanipulasi. Sistem informasi ini bertujuan menyelesaikan masalah seperti mengimplementasikan proses bisnis menggunakan konsep Enterprise Resource Planning (ERP) yang bertujuan untuk mempermudah dalam bagian administrasi di Balai desa. Sistem informasi ini dibangun berdasarkan data-data yang telah dikumpulkan dari Balai desa yang kemudian dianalisis dan dirancang guna untuk mempermudah karyawan dalam penginputan data dan sebagainya. ERP digunakan untuk menghubungkan dan menjalankan suatu proses bisnis di Sistem informasi. Dari penjelasan tersebut maka di dapat topik dengan judul "Rancang Bangun Sistem Informasi Resource Planning Desa" Sistem ini dibangun dengan menggunakan SDLC Prototype, Codeigniter, MySQL 4.6.5.2, HTML, dan PHP. Rancang bangun sistem informasi resource planning telah berhasil dikembangkan dengan menggunakan metode prototype, sistem informasi telah di uji dan berjalan sesuai dengan yang diinginkan.
\end{abstract}

Kata Kunci: ERP, Enterprise Resource Planning, Balai desa

Abstract
Information systems are now common to the corporate world where information systems are needed for a company so that it can help a work process becomes easier and faster. Information system is a device that can process data, store data and also manipulate. This information system aims to solve problems such as implementing business processes using the concept of Enterprise Resource Planning (ERP) which aims to facilitate the administration of the village hall. This information system is built based on data that has been collected from the village hall which is then analyzed and designed to make it easier for employees to input data and so on. ERP is used to connect and run a business process in an information system. From these explanations, a topic with the title "Design and Development of Village Resource Planning Information System" This system was built using SDLC Prototype, Codeigniter, MySQL 4.6.5.2, HTML, and PHP. The design of the resource planning information system has been successfully developed using the prototype method, the information system has been tested and run as desired.

Keywords: ERP, Enterprise Resource Planning, village halls

\section{Pendahuluan}

Teknologi informasi kini yang semakin berkembang pada era ini membuat segala sesuatu menjadi lebih cepat. Dalam penelitian ini peneliti mencoba memodelkan dan mengimplementasikan sebuah proses bisnis dengan menggunakan konsep Enterprise Resource Planning sebagai landasan dalam pembangunan sebuah sistem Enterprise Resource Planning pada perusahaan [1]. Balai desa Mojorejo merupakan salah satu balai desa yang terletak di jalan Ir.Soekarno Mojorejo Batu balai desa ini merupakan letak dimana kepala desa, aparat desa serta masyarakat melakukan kegiatan administrasi desa dan berkumpulnya warga pada waktu mengadakan musyawarah, pertemuan atau kegiatan lain.

Balai desa ini sudah mempunyai sistem informasi profil desa dan SISKEUDES (Sistem Keuangan Desa) yang telah dibuatkan oleh pemerintah sehingga administrasi keuangan desa dapat tertera dengan jelas dan sesuai dengan format pemerintah kemudian sistem profil desa 
Mojorejo ini dibuat untuk memberitahukan program apa saja yang sedang balaidesa jalankan dan informasi seputar desa seperti informasi dana desa dan rencana pembangunan desa yang akan dilaksanakan.

RAB (Rencana Anggaran Biaya) pada desa masih dibuat secara manual dengan Ms. Excel sehingga rencana pembangunan ini balai desa membutuhkan waktu untuk membuat RAB karena masih dibuat dengan cara manual, saat ini penggunaan MS. Excel sebagai media peyimpanan data masih memiliki keamanan yang rendah karena semua orang bisa memanipulasi data yang ada didalamnya sedangkan pada sistem yang diajukan, data tersimpan dalam database server yang terproteksi dengan password, hanya admin saja yang bisa memanipulasi data secara langsung. Berdasarkan hasil wawancara, terdapat beberapa masalah yang bisa timbul dengan sistem saat ini diantaranya adalah, kehilangan data karena penyimpanan kurang aman, adanya manipulasi data oleh pihak yang tidak berwenang, terjadinya kesalahan input, sistem keamanan data yang masih kurang. Permasalahan-permasalahan itu tentunya dapat memberikan dampak yang kurang baik pada kelancaran pembuatan rencana anggaran biaya yang akan dibuat. Sehingga perlu adanya sebuah sistem informasi untuk pembuatan RAB dan menerapkan Enterprise Resource Planning tersebut supaya data dapat terinegrasi dengan baik dan dapat memanajemen data dan juga meminimalisir terjadinya kesalahan.

Penerapan sistem Enterprise Resource Planning ke dalam perusahaan adalah salah satu strategi yang banyak digunakan oleh perusahaan untuk meningkatkan kualitas sistem informasinya. Hal ini dikarenakan Enterprise Resource Planning merupakan bagian dari infrastruktur perusahaan yangdapatmenunjang kelancaran proses bisnis perusahaan yang menerapkannya sistem tersebut [2] .

Enterprise Resource Planning adalah sebuah konsep untuk merencanakan dan mengelola sumber daya perusahaan meliputi dana,manusia,mesin, suku cadang, waktu, material dan kapasitas yang mempengaruhi luas mulai dari manajemen paling atas hingga operasional di sebuah perusahaan supaya dapat dimanfaatkan dengan optimal agar menghasilkan nilai tambah seluruh pihak berkepentingan (stake holder) atas perusahaan tersebut [3].

Beberapa Software seperti Openbravo adalah software Enterprise Resource Planning yang dapat dipergunakan oleh perusahaan terutama untuk perusahaan yang tergolong usaha kecil sampai menengah dan fitur-fiturnya bisa disesuaikan dengan kondisi yang ada di perusahaan [4]

\section{Metode Penelitian \\ 2.1 Prototype}

Prototyping merupakan suatu pendekatan dalam rekayasa perangkat lunak yang secara langsung mendemonstrasikan kepada pelanggan bagaimana sebuah software atau komponenkomponen software akan bekerja dalam lingkungannya sebelum tahapan konstruksi aktual dilakukan [5]. Berikut adalah proses model prototyping:

1. Pengumpulan kebutuhan : pelanggan dan pengembang bersama menentukan tujuan umum, kebutuhan yang diketahui dan gambaran bagian-bagian yang akan dibutuhkan berikutnya. Detail kebutuhannya tidak perlu dibicarakan disini.

2. Perancangan : langkah ini membuat beberapa perancangan sementara yang berfokus pada penyajian kepada kliennya (seperti membuat format input dan output).

Bagian arus sumber daya bisnis dari ERP yang terintegrasikan dengan tata kelola pemerintahan desa yaitu, uang dengan dana desa adalah sumber dana utama untuk membangun sebuah bisnis. Bahan mentah atau bahan baku akan berhubungan dengan bahan material dan pesanan pembelian juga berfungsi untuk mengatur transaksi pembelian sebuah bahan atau peralatan. Gaji pegawai atau upah untuk pekerja juga berhubungan dengan bagian pekerjaan dimana bagian pekerjaan yang sudah diatur untuk masing-masing pekerjaan.

3. Evaluasi prototype : klien mengevaluasi prototype yang telah dibuat apakah yang dibangun sudah sesuai dengan keinginan klien atau masih belum.

Perulangan ketiga proses ini terus berlangsung hingga semua kebutuhan terpenuhi. Prototype-prototype dibuat untuk memuaskan kebutuhan klien, untuk memahami kebutuhan klien lebih baik. Prototipe yang dibuat dapat dimanfaatkan kembali untuk membangun software

REPOSITOR, Vol. 2, No. 7, Juli 2020: 871-880 
lebih cepat, namun tidak semua prototype bisa dimanfaatkan. Skema dari prototype secara umum seperti pada Gambar 1.

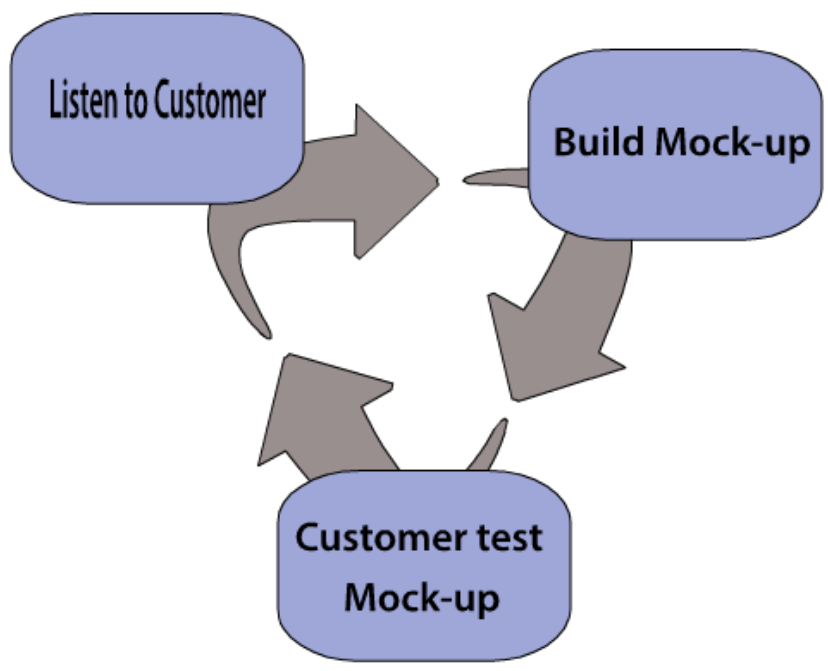

Gambar 1.Skema Prototipe [6]

Dalam model prototype dari software yang dihasilkan kemudian dilakukan uji coba atau test kepada pelanggan, dan pelanggan tersebut dapat kesempatan untuk memberikan masukan sehingga software yang dihasilkan benar benar sesuai dengan keinginan klien tersebut

\subsection{Enterprise Resource Planning}

Enterprise Resource Planning berkembang dari Manufacturing Resouces Planning (MRP II) dimana MRP II sendiri adalah hasil evalusi dari Material Requirement Planning (MRP) yang berkembang sebelumnya. Sistem Enterprise Resource Planning secara modular biasanya menangani proses manufaktur, logistik, distribusi persediaan (inventori), pengapalan, invoice dan akunting perusahaan. Ini berarti bahwa sistem ERP dapat membantu mengontrol aktivitas bisnis seperti penjualan, pengiriman, produksi, manajemen persediaan, manajemen kualitas dan sumber daya manusia.

Enterprise Resource Planning dan pendahulunya, Manufacturing Resource Planning (MRP II), memungkinkan terjadinya kemajuan yang sangatbesar dalam manajemen prosesproses manufaktur. Enterprise Resource Planning juga salah satu faktor penyumbang pada performa ekonomi Amerika yang luar biasa pada era 1990-an. Tidak diragukan lagi bahwa Enterprise Resource Planning adalah tonggak sejarah dalam proses industri.

Perencanaan sumber daya perusahaan, atau sering disingkat Enterprise Resource Planning dari istilah Enterprise Resource Planning, merupakan sebuah sistem informasi yang dikhususkan bagi perusahan dalam bidang manufaktur maupun jasa yang memiliki berperan menghubungkan dan menjalankan suatu proses bisnis yang saling berhubungan dengan aspek operasi, produksi ataupun distribusi di perusahaan tersebut [1]. Enterprise Resource Planning memiliki tahapan-tahapan pengembangan sebuah Enterprise Resource Planning.

1. Tahap Perencanaan : Langkah pertama yang dilakukan dalam implementasi adalah mengidentifikasi tujuan utama dan ruang lingkup proyek tersebut.

2. Tahap Analisis : Pada fase ini dikembangankan sebuah uji coba sistem Enterprise Resource Planning di berbagai area untuk kebutuhan simulasi dan menunjukkan bagaimana integrasi antar modul-modul terhadap user dan identifikasi kebutuhan lainnya.

3. Tahap Desain: Pada tahapan desain, desain mulai dikembangkan. Pada fase ini, end user harus diberikan latihan yang intensif terhadap paket-paket Enterprise Resource Planning supaya user dapat menggunakan sistem yang baru.

4. Tahap Implementasi: Fase berikutnya adalah melakukan proses implementasi. 
5. Tahap Dukungan Teknis: Tujuan dari fase ini adalah untuk menjamin keberhasilan dari sistem pada jangka pendek dan sistem jangka panjang [1].

Sistem Enterprise Resource Planning mencatat arus sumber daya bisnis (seperti bahan mentah, kapasitas produksi dan uang), dan status dari perjanjian yang dibuat dalam proses bisnis (seperti gaji pegawai, pesanan pelanggan maupun pembelian), tidak peduli departemen mana (penjualan, akunting, manufacturing, dsb) yang memasukkan data ke dalam sistem [7].

Adapun beberapa keuntungan menerapkan Enterprise Resource Planning pada sistem informasi antara lain dapat disebutkan sebagai berikut:

1. Integrasi bisnis dan akurasis data yang lebih baik.

2. Perencanaan dan manajemen sistem informasi.

3. Peningkatan efisiensi dan produktifitas.

4. Pembentukan standarisasi prosedur.

\section{Hasil Penelitian dan Pembahasan}

Metodologi yang digunakan dalam pembuatan sistem informasi resource planning desa mojorejo. Langkah-langkah dalam metodologi tersebut meliputi pengumpulan data permintaan customer, build yang terdiri dari analisa kebutuhan, perancangan sistem, implementasi system (coding), pengujian serta pengambilan kesimpulan. Gambar 2 merupakan diagram yang menjelaskan mengenai metodologi yang digunakan.

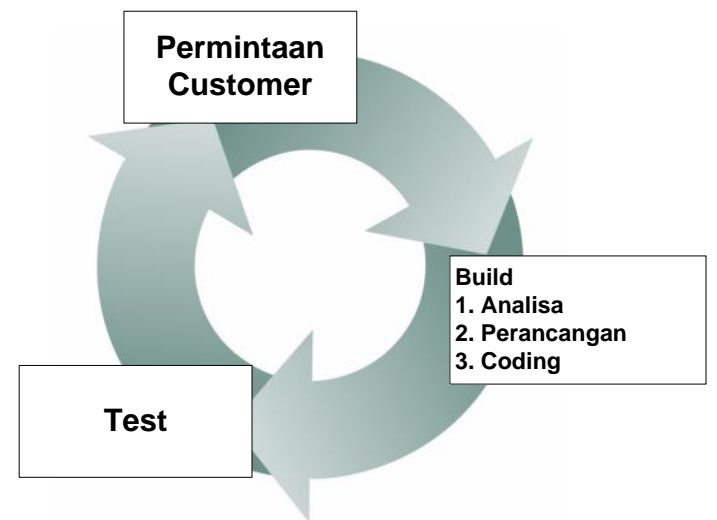

Gambar 2. Diagram Metodologi

\subsection{Permintaan Custommer}

Permintaan customer merupakan proses awal dalam menganalisa sistem yang akan di bangun. Permintaan customer diambil dari dokumen-dokumen yang terkait dengan sistem. Analisis dokumen merupakan kegiatan pengumpulan informasi mengenai dokumen-dokumen yang digunakan dalam suatu sistem. Tujuan dari analisis dokumen adalah mengetahui dan memahami dokumen-dokumen apa saja yang terlibat dan mengalir dalam suatu sistem yang sedang berjalan.

\subsubsection{Tahap Pengembangan}

Tahap pengembangan merupakan tahapan proses yang menjelaskan tentang kebutuhan client dan hasil developer yang saling melengkapi. Berikut merupakan Tabel 1 tahapan pengembangan.

Tabel 1. Tahapan Pengembangan

\begin{tabular}{|c|c|c|}
\hline No & Client & Developer \\
\hline 1 & $\begin{array}{l}\text { Meminta untuk di buatkan } \\
\text { aplikasi yang dapat mempermudah } \\
\text { pencatatan dan pelaporan sederhana }\end{array}$ & $\begin{array}{l}\text { Menganalisa form dan alur } \\
\text { system manual dan membuat daftar } \\
\text { kebutuhan system }\end{array}$ \\
\hline 2 & $\begin{array}{l}\text { Memvalidasi daftar kebutuhan } \\
\text { system yang telah di buat oleh } \\
\text { developer }\end{array}$ & $\begin{array}{l}\text { Membuat rancangan system } \\
\text { berdasarkan hasil analisa dan } \\
\text { kebutuhan sistem }\end{array}$ \\
\hline
\end{tabular}

REPOSITOR, Vol. 2, No. 7, Juli 2020: 871-880 

developer developer

Merevisi hasil evaluasi client

Mulai membangun sistem

\subsection{Build}

\subsubsection{Analisa}

RAB (Rencana Anggaran Biaya) pada desa masih dibuat secara manual dengan Ms. Excel sehingga rencana pembangunan ini Balai desa membutuhkan waktu untuk membuat RAB karena masih dibuat dengan cara manual, saat ini penggunaan MS.Excel sebagai media peyimpanan data masih memiliki keamanan yang rendah karena semua orang bisa memanipulasi data yang ada di dalamnya sedangkan pada sistem yang diajukan, data tersimpan dalam database server yang terproteksi dengan password, hanya admin saja yang bisa memanipulasi data secara langsung. Berdasarkan hasil wawancara, terdapat beberapa masalah yang bisa timbul dengan sistem saat ini diantaranya adalah, kehilangan data karena penyimpanan kurang aman, adanya manipulasi data oleh pihak yang tidak berwenang, terjadinya kesalahan input, sistem keamanan data yang masih kurang. Permasalahan-permasalahan itu tentunya dapat memberikan dampak yang kurang baik pada kelancaran pembuatan rencana anggaran biaya yang akan dibuat.

\subsubsection{Perancangan}

Pada Gambar 3, usecase diagram merupakan sebuah fungsional diagram yang menggambarkan fungsi dasar dari sistem, yaitu apa yang dapat digunakan oleh pengguna dan bagaimana sistem harus merespon terhadap aksi pengguna.

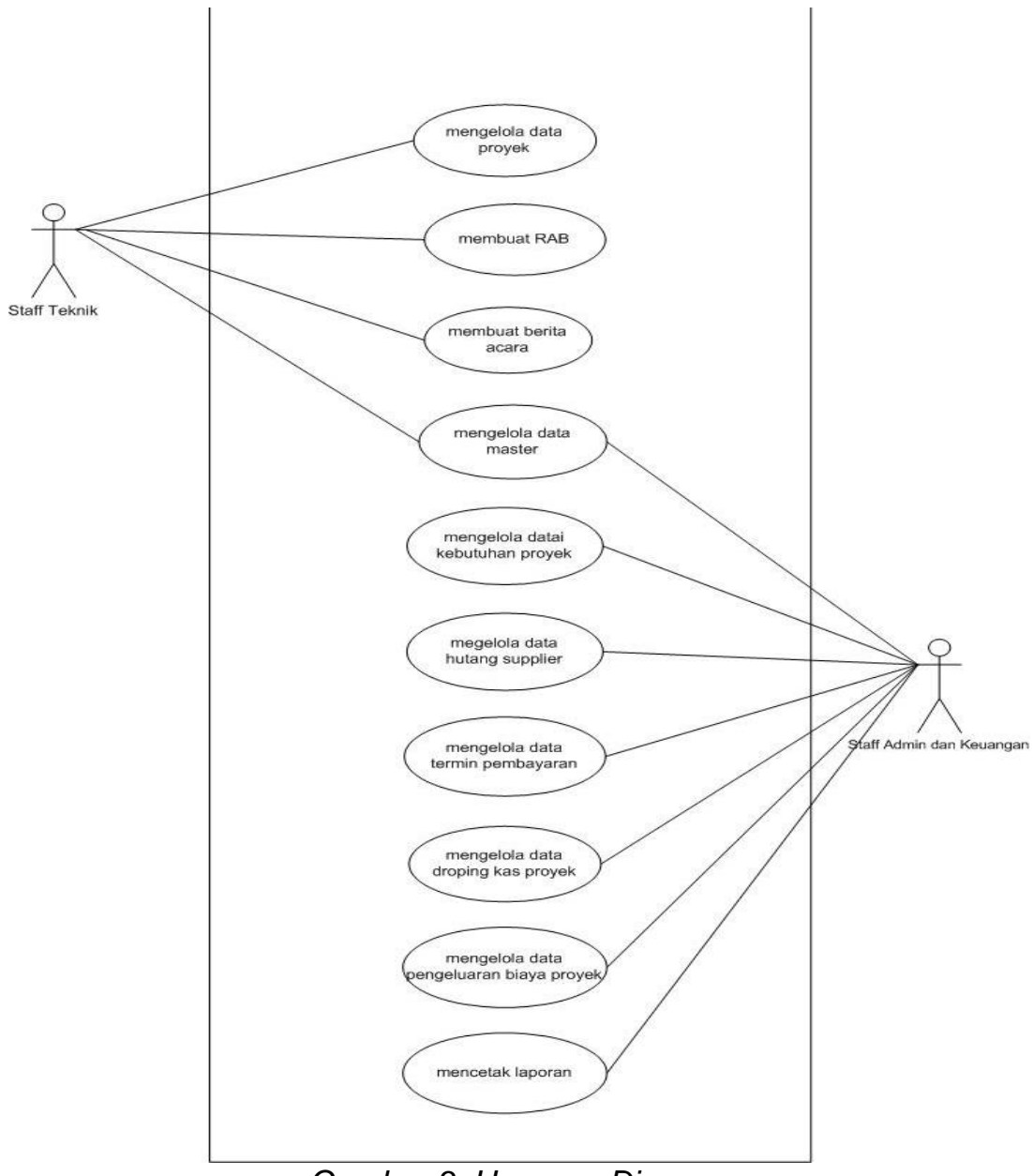

Gambar 3. Usecase Diagram

Rancang Bangun Sistem Informasi Resource... Adi Bagus Setiawan, Galih Wasis Wicaksono, Ilyas Nuryasin 
Pada Gambar 4, aktivitas diagram mengelola data proyek menggambarkan bagaimana Staff Teknik melakukan input data proyek. Setelah masuk ke halaman utama Staff Teknik memilih menu perencanaan proyek kemudian memilih submenu inisiasi proyek untuk menampilkan data proyek, untuk menambah data staff teknik memilih tombol tambah sehingga form penginputan data proyek akan terbuka. Staff Teknik mengisi form input dan dapat memilih aksi menghapus atau mengedit data proyek.

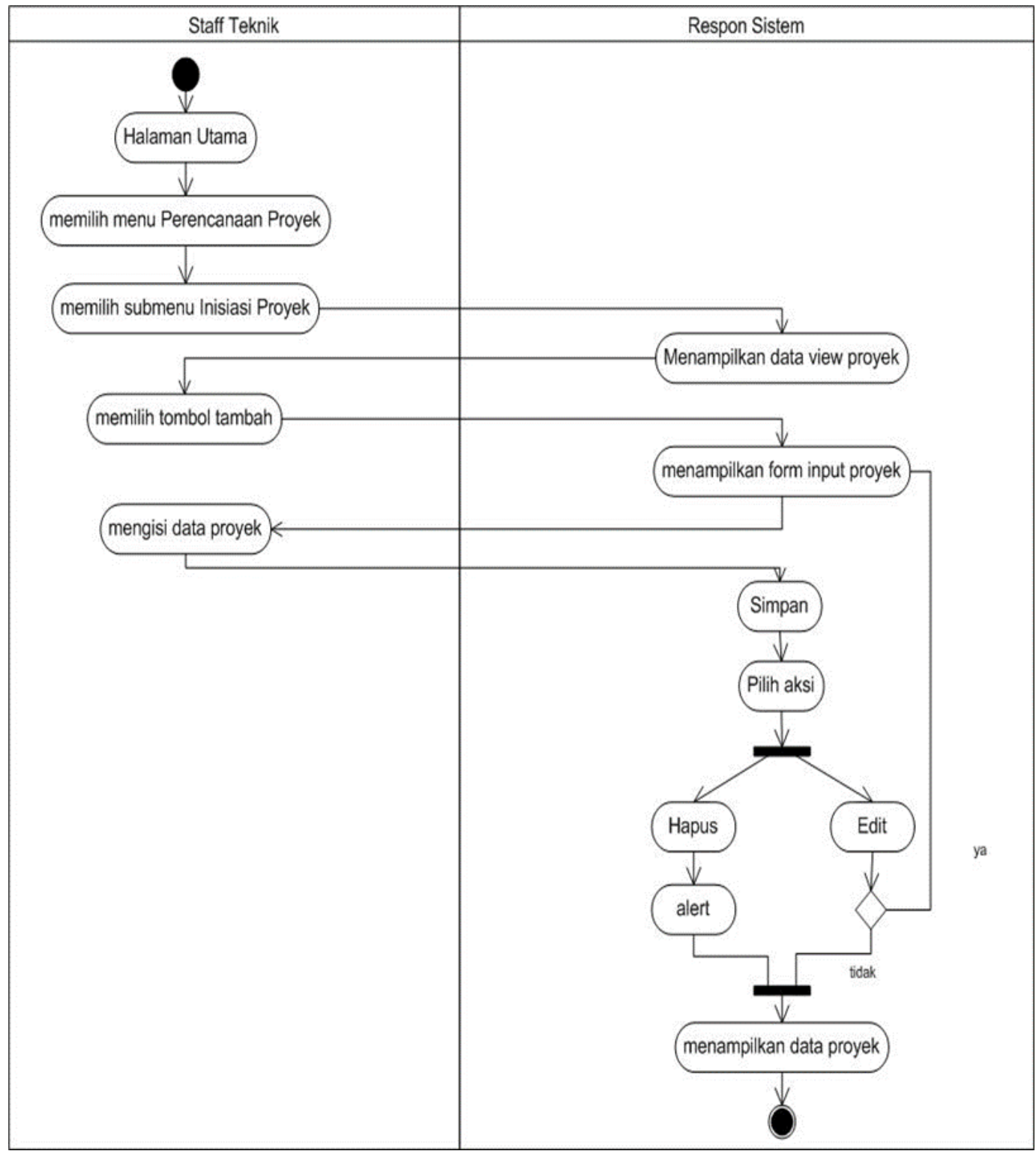

Gambar 4. Activity Diagram

Sequence diagram menggambarkan interaksi antara objek-objek yang terjadi di dalam sistem aplikasi. Gambar 5 berikut adalah sequence diagram untuk aplikasi manajemen proyek kontraktor Unit Desa Kajang. 


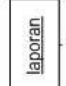

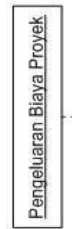
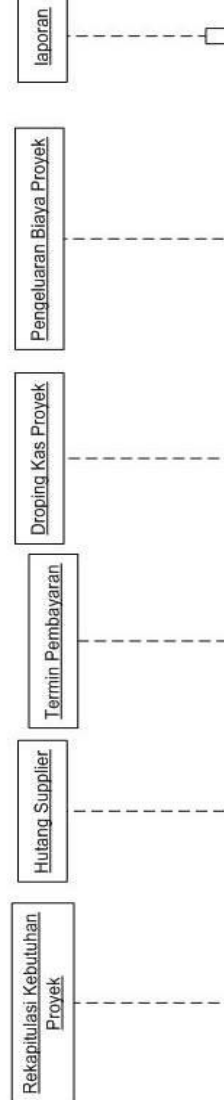

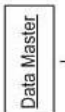

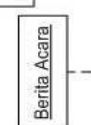

욌

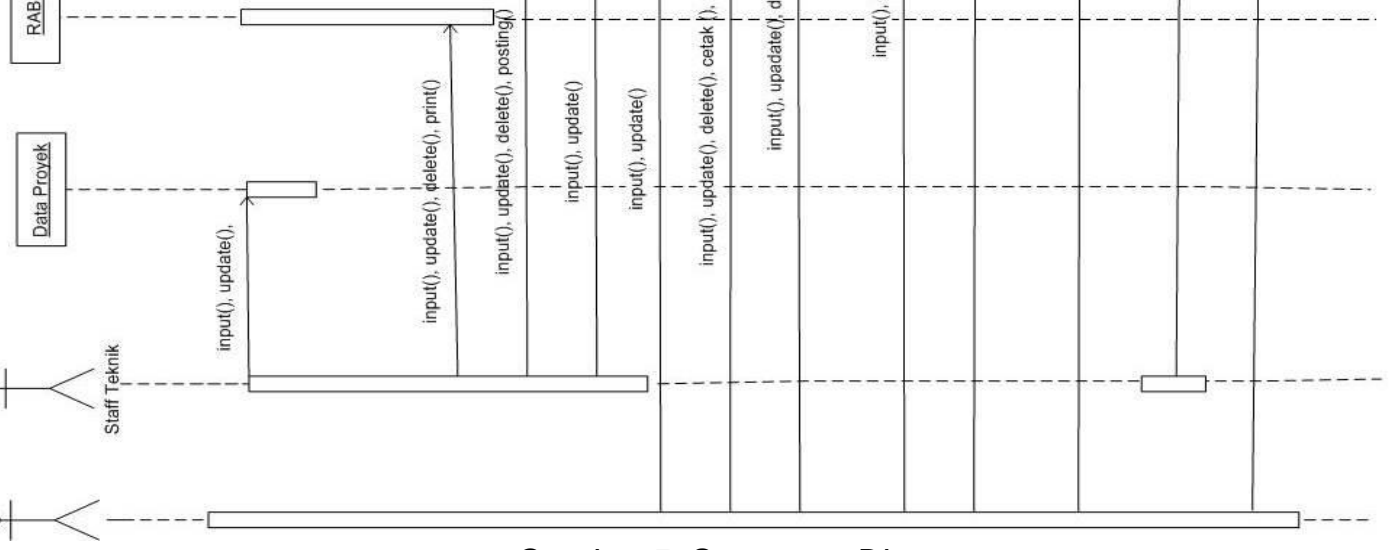

Gambar 5. Sequence Diagram

Class diagram pada Gambar 6 menjelaskan hubungan antar class dalam sebuah sistem yang sedang dibuat dan bagaimana caranya agar mereka saling berkolaborasi untuk mencapai sebuah tujuan. 


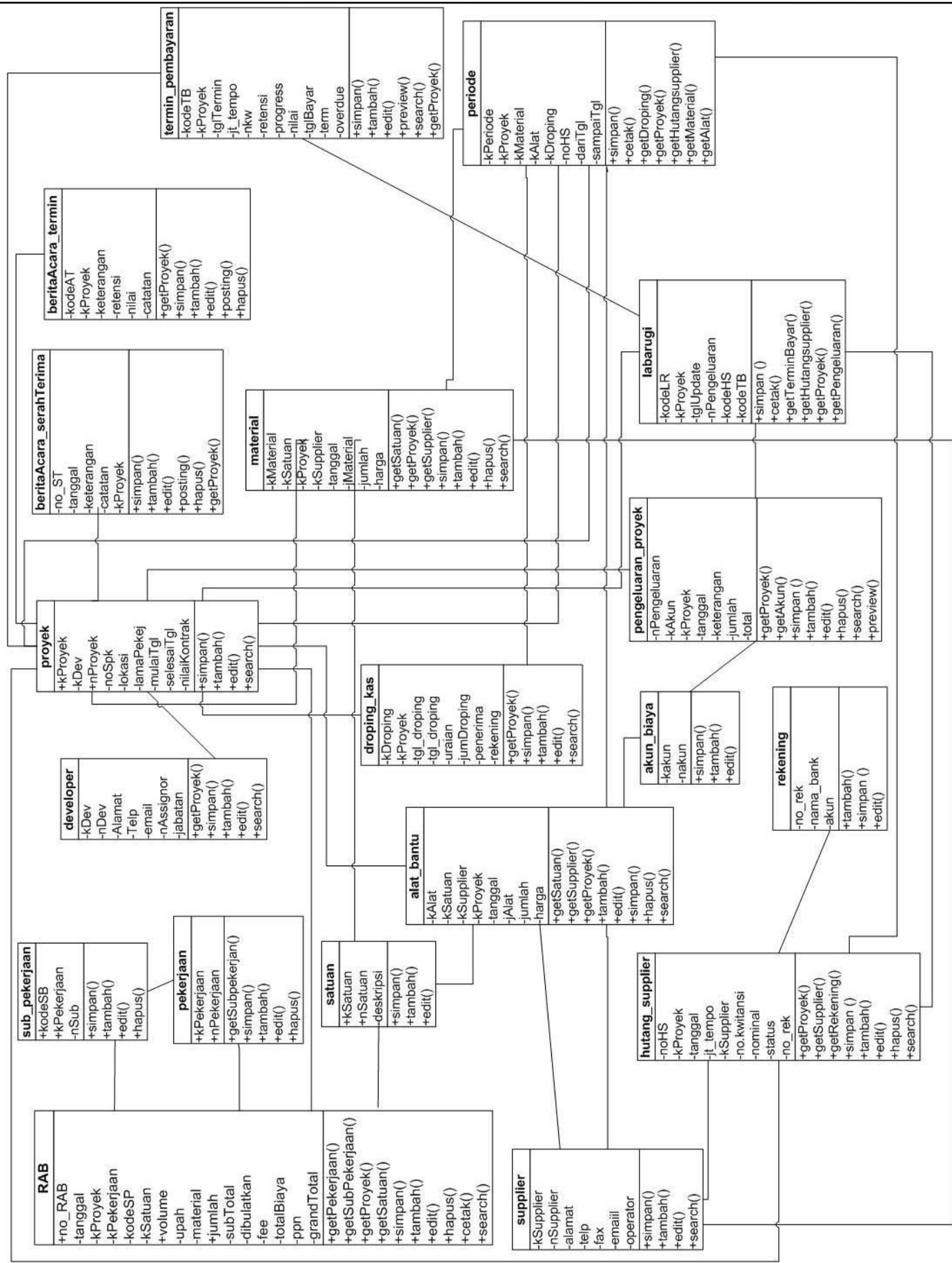

Gambar 6. Class Diagram

\subsubsection{Coding dan Implementasi}

Implementasi sistem informasi manajemen RAB merupakan tahap dimana sistem yang sudah dirancang, lalu diimplementasikan untuk menghasilkan sistem yang sesuai dengan yang diinginkan dan siap dioperasikan pada keadaan yang sebenarnya. Dari hal ini dapat diketahui apakah sistem yang dihasilkan sesuai dengan tujuan yang diinginkan atau tidak.

Pada Gambar 7, jika login sebagai admin maka ada pilihan menu yang bisa digunakan oleh admin yaitu menu beranda terdapat tiga pilihan menu yaitu data master, transaksi dan laporan yang masing-masing memiliki fungsi tertentu. 


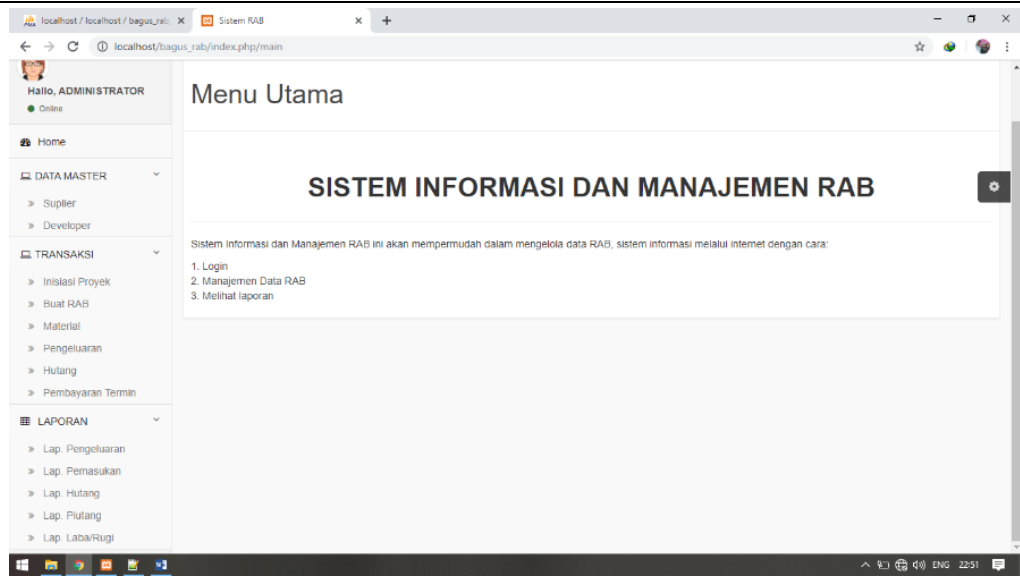

Gambar 7. Tampilan Menu Halaman Admin

Halaman manajemen Proyek atau Manajemen data manajemen proyek Gambar 8 merupakan halaman yang akan tampil ketika admin melakukan klik pada menu manajemen proyek, pada halaman manajemen proyek terdapat table yang menampilkan daftar proyek yang telah tersimpan dalam database, dan terdapat tombol tambah, edit, hapus semua, hapus manajemen proyek.

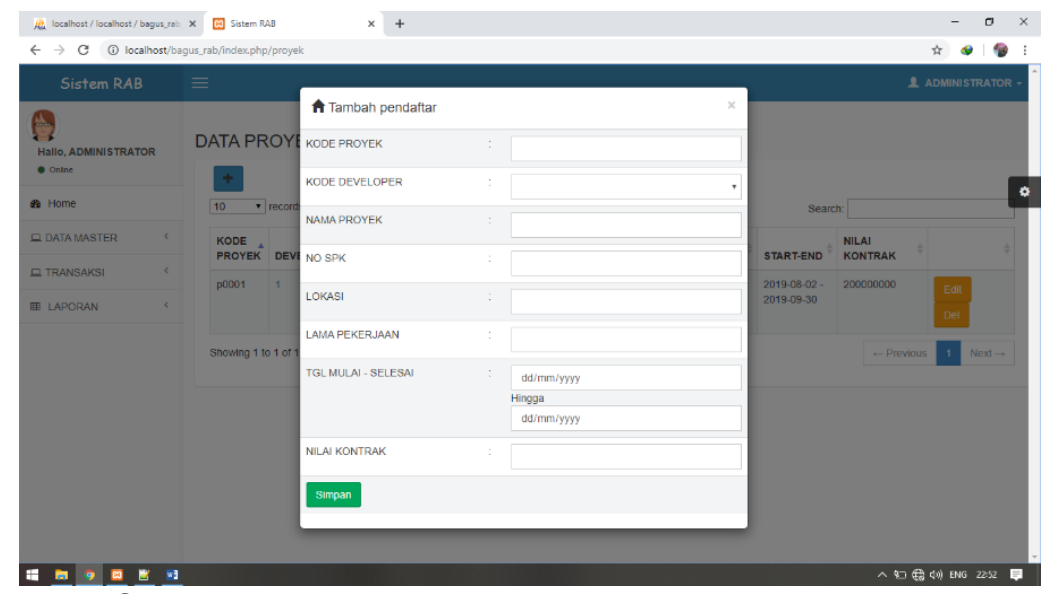

Gambar 8. Tampilan Tambah Data Manajemen Proyek

Pada Gambar 9, halaman laporan pengeluaran merupakan halaman yang akan memaparkan seluruh transaksi pengeluaran yang di lakukan. Pada halamana laporan pengeluaran terdapat tombol print yang berfungsi untu melakukan pencetakan dokumen.

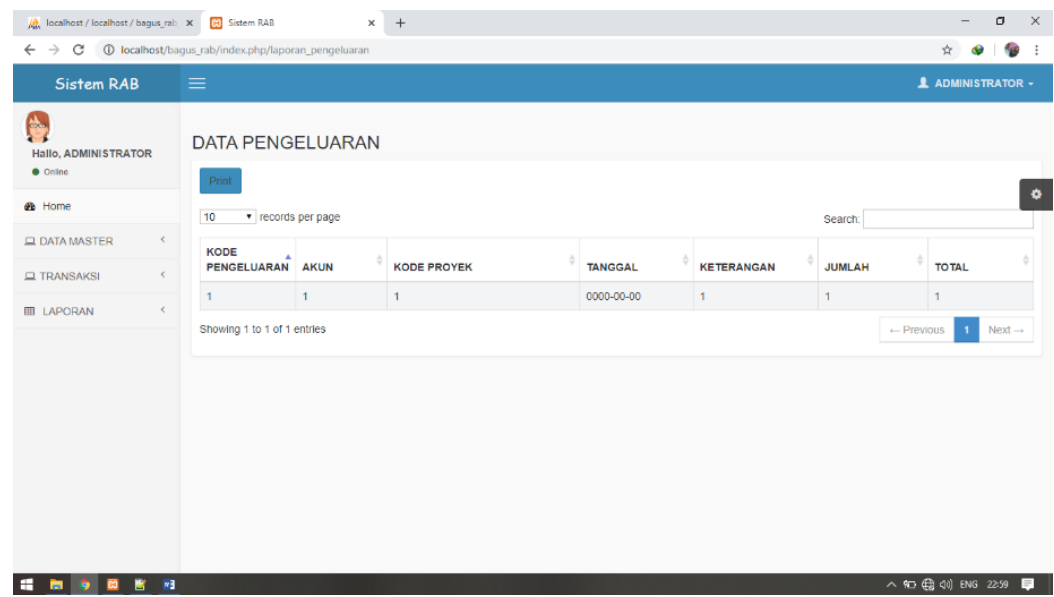

Gambar 9. Tampilan Menu Laporan Data Pengeluaran 


\subsection{Testing}

Testing disini peneliti menggunakan metode black box testing yang dimana setelah di uji sudah sesuai dengan apa yang di inginkan

\section{Kesimpulan Dan Saran}

Pada bab ini berisikan kesimpulan dari hasil penelitian yang telah diperoleh dan terdapat saran untuk pengembangan topic tugas akhir yg sejenis:

\subsection{Kesimpulan}

1. Sistem dapat membantu proses penyampaian informasi dan manajemen data RAB dengan baik.

2. Berdasarkan bukti uji pada pengujian blackbox hasilLpengujian sistem menunjukkan bahwa sistemLdapat berjalan dengan baik sesuai dengan butir uji yang diujikan.

\subsection{Saran}

Dapat diintegrasikan dengan beberapa aplikasi yang berhubungan dengan sistem misalnya terintegrasi dengan sistem pergudangan, sistem akuntansi dan sistem lainnya. Aplikasi belum menitik beratkan user experience dan pada sistem keamanan sehingga masih belum dapat dikatakan sempurna.

\section{Referensi}

[1] R. Al Aziz, F. Amalia, and A. Hendra Brata, "Pembangunan Sistem Enterprise Resource Planning pada Griya Laundry," J. Pengemb. Teknol. Inf. dan IImu Komput. Univ. Brawijaya, vol. 2, no. 6, pp. 2278-2285, 2018.

[2] R. Akbar and J. Juliastrioza, "Penerapan Enterprise Resource Planning (ERP) untuk Sistem Informasi Pembelian, Persedian dan Penjualan Barang pada Toko EMI Grosir dan Eceran," J. Nas. Teknol. dan Sist. Inf., vol. 1, no. 1, pp. 7-17, 2015, doi: 10.25077/teknosi.v1i1.2015.7.

[3] N. I. Shofawaty, "Analisis Dan Iplementasi Modul Vocher Financial Management Pada Open ERP," J. Chem. Inf. Model., vol. 53, no. 9, pp. 1689-1699, 2019, doi: 10.1017/CBO9781107415324.004.

[4] T. R. Nofri and G. P. Liansari, "Pt World Yamatex Spinning Mills Bandung Enterprise Resource Planning ( Erp ) Rancangan Implementasi," vol. 03, no. 01, pp. 272-283, 2015.

[5] E. Prianto, A. Yudhana, and A. Fadlil, "Analisis Perancangan Aplikasi Administrasi Kepegawaian Dan Kegiatan Berbasis Android," pp. 63-68, 2017.

[6] A. D. A. Rani Susanto, "Perbandingan Model Waterfall Dan Prototyping Untuk Pengembangan Sistem Informasi," Ther. Ggw., vol. 111, no. 5, p. 756-757 passim, 1972.

[7] V. L. Kurniawan, C. Tonyjanto, and A. I. Datya, "Perancangan Sistem Informasi Dengan Metode Enterprise Resource Planning ( Erp ) Untuk Manajemen Dan Inventori Pada Apotek Kharisma Farma Denpasar," J. Teknol. Inf. dan Komput., vol. 3, no. 1, pp. 295-303, 2017, doi: 10.36002/jutik.v3i1.231. 